$12-2018$

\title{
New Documents Shed Light: Why Did Peacekeepers Withdraw during Rwanda's 1994 Genocide?
}

\author{
Emily A. Willard \\ University of Washington
}

Follow this and additional works at: https://digitalcommons.usf.edu/gsp

\section{Recommended Citation}

Willard, Emily A. (2018) "New Documents Shed Light: Why Did Peacekeepers Withdraw during Rwanda's 1994 Genocide?," Genocide Studies and Prevention: An International Journal: Vol. 12: Iss. 3: 143-162. DOI:

https://doi.org/10.5038/1911-9933.12.3.1611

Available at: https://digitalcommons.usf.edu/gsp/vol12/iss3/14

This is brought to you for free and open access by the Open Access Journals at Digital Commons @ University of South Florida. It has been accepted for inclusion in Genocide Studies and Prevention: An International Journal by an authorized editor of Digital Commons @ University of South Florida. For more information, please contact digitalcommons@usf.edu. 


\section{New Documents Shed Light: Why Did Peacekeepers Withdraw during Rwanda's 1994 Genocide?}

\section{Acknowledgements}

The author thanks Tom Blanton of the National Security Archive for his leadership on the "International Decision-Making in the Age of Genocide: Rwanda 1990-1994" project. The author thanks Angelina Godoy at the University of Washington for her support and feedback in the writing of this paper. 


\title{
New Documents Shed Light: Why Did Peacekeepers Withdraw during Rwanda's 1994 Genocide?
}

\author{
Emily Willard \\ University of Washington \\ Seattle, Washington, USA
}

The genocide in Rwanda in 1994, during which 800,000 to one million Tutsi and moderate Hutus were killed in 100 days, is infamous not only for how brutally and quickly the killing took place, but also because of the failure of the international community to act to stop the violence. Why did the international community fail to intervene in time? Extensive studies have been conducted to better understand how the genocide unfolded on the ground as well as why the United Nations stood by as horror engulfed Rwanda. ${ }^{1}$ However, questions still remain about the international community's response, in particular the role of the United States.

Newly declassified documents indicate that the United States took the lead in encouraging the international community to call for withdrawal of the United Nations peacekeeping troops who were on the ground when the genocidal violence started in April of 1994, a continuance of a larger policy shift away from United States involvement in peacekeeping. ${ }^{2}$ These documents also further illuminate the political atmosphere in which the Clinton administration was pulling back from peace keeping, even prior to the Somalia crisis in October 1993. This paper reports findings of a research study to understand international decision-making before and during the Rwanda genocide, making four major contributions to scholarship about the Rwanda genocide in particular, and genocide studies and prevention literature in general.

Information obtained through newly declassified U.S. government documents and results from a "critical oral history" 3 conference shed light on, firstly, the timeline of U.S. decision-making on peacekeeping in Rwanda. The evidence shows that United States was not in favor of supporting the United Nation's mission in Rwanda as of late September, prior to the United Nations (UN) troops' arrival, and prior to the killing of U.S. troops in Somalia in early October 1993. ${ }^{4}$ To be sure, existing research acknowledges the overall draw down of US peacekeeping missions after the end of the Cold War, however other scholarship and former political officials focus on the dominant role of "Somalia syndrome" as the reason for U.S. drawdown in peacekeeping participation. ${ }^{5}$ The decision to limit the Rwandan peacekeeping mission and general discussions of a shift in U.S. policy resulting in Presidential Decision Directive 25 (PDD-25) was made prior to the Somalia crisis. United States policy makers in the National Security Council (NSC) were looking for a reason to

${ }^{1}$ Samantha Power, A Problem from Hell: America and the Age of Genocide (New York: Basic Books, 2002); Linda Melvern, A People Betrayed: The Role of the West in Rwanda's Genocide (Cape Town, London, and New York: Zed Books, 2000); Linda Melvern, Conspiracy to Murder: The Rwandan Genocide (London and New York: Verso, 2006), Michael Barnett, Eyewitness to a Genocide - The United Nations and Rwanda (Ithaca and London: Cornell University Press, 2002); Alison Des Forges, "Leave None to Tell the Story": Genocide in Rwanda (New York: Human Rights Watch, 1999); Gérard Prunier, The Rwanda Crisis: History of a Genocide (New York: Columbia University Press, 1995); Matthew Levinger, "Why the U.S.

Government Failed to Anticipate the Rwandan Genocide of 1994: Lessons for Early Warning and Prevention," Genocide Studies and Prevention 9, no. 3 (2016), 33-58, accessed March 28, 2017, doi: 10.5038/1911-9933.9.3.1362; Howard Adelman and Astri Suhrke, "Early Warning and Response: Why the International Community Failed to Prevent the Genocide?" Disasters 20 (1996), 295-304; Fred Grünfeld, and Anke Huijboom, The Failure to Prevent Genocide in Rwanda: The Role of Bystanders (Leiden and Boston: Martinus Nijhoff Publishers, 2007); Daniela Kroslak, The French Betrayal of Rwanda (Bloomington and Indianapolis: Indiana University Press, 2008).

2 Tom Blanton and Emily Willard, "1994 Rwanda Pullout Driven by Clinton White House, U.N. Equivocation," Electronic Briefing Book no. 511, Washington, DC: National Security Archive, April 16, 2015, accessed March 28, 2017, https://nsarchive2.gwu.edu/NSAEBB/NSAEBB511/.

${ }^{3} \mathrm{~A}$ research methodology that brings together policy makers and declassified government records, developed by James Blight and janet Lang. See further discussion in methodology section of this paper.

${ }^{4}$ National Security Archive, "International Decision-Making in the Age of Genocide: Rwanda 1990-1994, Annotated Transcript, Day 2," Washington, DC: U.S. Holocaust Memorial Museum and National Security Archive, June 2, 2014, accessed March 28, 2017, https://www.ushmm.org/m/pdfs/20150325-rwanda-transcript-day-two.pdf.

${ }^{5}$ Barnett, Eyewitness to a Genocide, 36-37; John Shattuck, Freedom on Fire: Human Rights Wars and America's Response (Cambridge, MA: Harvard University Press, 2003), 22; George Moose, Interview by PBS Frontline, Frontline, November 21, 2003, accessed October 10, 2018, https://www.pbs.org/wgbh/pages/frontline/shows/ghosts/interviews/ moose.html; Boutros Boutros-Ghali, Interview by PBS Frontline, Frontline, January 24, 2004, accessed October 10, 2018, https://www.pbs.org/wgbh/pages/frontline/shows/ghosts/interviews/ghali.html; Grünfeld and Huijboom, The Failure to Prevent, 142. 
limit support, and the killing of US troops in Somalia was the perfect opportunity. This paper, however, does not go so far as to suggest that there was no link between the Somalia crisis and the United States' decision to limit support for the peacekeeping mission in Rwanda. ${ }^{6}$ The records show that the movement to pull back on U.S. peacekeeping began prior to Somalia, and the killing of U.S. troops in October 1993 provided additional momentum for this cause.

Secondly, evidence suggests that the United States used the killing of Belgium peacekeepers to call for a full withdrawal of troops which resulted in the drawdown of the United Nations Assistance Mission in Rwanda (UNAMIR) instead of sending reinforcements, which UNAMIR leadership on the ground and Belgium had originally requested. This is a continuation of the more general policy where the United States was looking for reasons to disengage from peacekeeping. New evidence further clarifies the argument against the scapegoating of Belgium and contradicts other arguments that the United States call for withdrawal was merely a defensive reaction due to the Somalia crisis, and a move to give Belgium cover in order to save face. ${ }^{7}$

Thirdly, this paper provides an example of the use of the critical oral history methodology in the study of historical events, leading to a better understanding of the event and suggests potential concrete changes to policy that can work to prevent genocide in the future. This paper calls for future utilization of this methodology and suggests ways to better include marginalized voices. Finally, the results of this study support scholarship that notes the weakness of the Department of State in U.S. foreign policy creation, and the argument that the NSC has "greater access to the president and more impact on strategic and crisis decision-making." ${ }^{8}$ The results speak to the power struggle between U.S. agencies for influence in decision-making, and the complicated nature of what influences U.S. foreign policy creation. ${ }^{9}$

These are important findings because they contribute additional key information, further illuminating the historical record of the international response to genocide in Rwanda, particularly of the United States. With a better understanding of how important policy decisions are made, it may be possible to influence these decisions in the future, leading to better genocide and mass atrocity prevention policy generally. For example, this research shows that key foreign policy decisions were made within the NSC, as opposed to Department of State staff. This research therefore has implications for scholars of the Rwandan genocide, as well as those interested in United States and international response to mass atrocity, and the making of U.S. foreign policy.

\section{Rwanda's Genocide Unfolds}

In August 1993, members of the Rwandan government, made up of mostly Hutus signed a peace agreement, the Arusha Accords, with the Rwanda Patriotic Front (RPF) a mostly Tutsi rebel group, ending decades of conflict that was rooted in Belgian colonialism and ethnic tensions. Both parties requested a U.N. peacekeeping operation to assist in implementing the provisions of the Arusha Accords, including establishing a transitional government and instituting a disarmament, demobilization, and reintegration (DDR) program, among other goals.

Through a fraught process, the United Nations Security Council (UNSC) debated the mandate and capacity of the peacekeeping operation. Eventually, this led to a narrow mandate for supporting the implementation of the Arusha Accords, and did not allow peacekeepers to use force. ${ }^{10}$ The UNSC passed a resolution to establish UNAMIR on October 5, 1993 with a small force of 2,548

\footnotetext{
${ }^{6}$ Flavia Gasbarri, "Revisiting the Linkage: PDD 25, Genocide in Rwanda and the US Peacekeeping Experience of the 1990s," The International History Review, 40, no. 4 (2017), https://doi.org/10.1080/07075332.2017.1354311.

${ }^{7}$ Grünfeld and Huijboom, The Failure to Prevent, 196; Adelman and Suhrke, Early Warning and Response, 300; Shattuck, Freedom on Fire, 34; Kroslak, French Betrayal of Rwanda, 207-210.

8 Steven Hook, "Domestic Obstacles to International Affairs: The State Department under Fire at Home," PS: Political Science and Politics 36, no. 1 (January 2003), 23-29, accessed March 28, 2017, doi: 10.1017/S1049096503001641.

${ }^{9}$ Lawrence Jacobs and Benjamin Page, “Who Influences U.S. Foreign Policy?" American Political Science Review 99, no. 1 (February 2005), accessed March 28, 2017, doi: 10.1017/S000305540505152X; Salah Oueslati. “U.S. Foreign Policy and the Complex Factors of Decision-Making," Society 51, no. 5 (2014), 472-481, accessed March 28, 2017, doi: 10.1007/ s12115-014-9813-y.

${ }^{10}$ Brent Beardsley, “U.N. Peacekeepers in Rwanda were Ill- Equipped," interview by Michael Dobbs, Genocide Prevention Project, April 30, 2013, Washington, DC: National Security Archive.
} 
troops and a narrow mandate that was "far short of what would have been needed to guarantee implementation of the Accords."11 UNAMIR was "constrained by the relatively small size of the force as well as by a determination not to repeat the mistakes made in Somalia."12

While this debate about UNAMIR was taking place at the United Nations, the United States was engaged in a domestic political debate about the future of U.S. involvement in peacekeeping operations. As such, the United States was reluctant to support UNAMIR from the beginning. Richard Clarke, the National Security Advisor for peacekeeping at the White House, felt that "news from Rwanda only confirmed a deep skepticism about the viability of UN deployments."13 This political debate and eventual call for a drawdown of U.S. peacekeeping activities would gain more momentum in the aftermath of the Somalia crisis in which U.S. troops were killed in a failed military option, during which one of the bodies of the soldiers was dragged through the streets of Mogadishu in October 1993, making nightly news across the United States. ${ }^{14}$ The reevaluation of the United States' role in peacekeeping would eventually result in the creation of the PDD-25, providing criteria to guide U.S. decision making on support for peacekeeping operations. These criteria called for a decrease in United States' involvement and restricted support for humanitarian intervention missions. ${ }^{15}$ While President Clinton did not sign PDD-25 until May 1994, the document influenced the United States' strategy for decision-making in response to the genocide in Rwanda before it was officially released. ${ }^{16}$

In the autumn of 1993, Canadian General Roméo Dallaire was named force commander of the peacekeeping operation consisting of contingents from Bangladesh, Ghana, Belgium, and other countries. The first troops arrived in Rwanda in early November, and the bulk of the force arrived on the ground in December, less than six months before the start of the genocide. ${ }^{17}$ From the beginning Dallaire and his troops struggled with a lack of provisions and support, never having received approval of standard Rules of Engagement (ROE) which guide the daily procedures of the mission. ${ }^{18}$

Over the next months, in late 1993 and early 1994, the Rwandan government failed to implement major milestones of the Arusha Accords, most importantly the Broad-Based Transitional Government, which was the first step to implementing other main pieces of the Accords, such as the DDR program. ${ }^{19}$ Dallaire and his troops struggled with basic lack of supplies as recorded daily in his situation reports back to New York. ${ }^{20}$ On January 11, 1994, Dallaire sent an urgent fax to New York about a weapons cache and possible plans of mass violence as reported by an informant. ${ }^{21}$ However, the United Nations Department of Peacekeeping Operations (DPKO) continued to deny Dallaire's requests for an expanded mandate, or needed supplies and equipment, despite the fax's warning. ${ }^{22}$

\footnotetext{
${ }^{11}$ Des Forges, Leave None to Tell the Story, 132.

${ }^{12}$ Ibid.

${ }^{13}$ Power, A Problem from Hell, 364.

${ }^{14}$ Barnett, Eyewitness to a Genocide, 37.

${ }^{15}$ Ibid., 41; Power, A Problem from Hell, 342.

${ }^{16}$ Power, A Problem from Hell, 342; Des Forges, Leave None to Tell the Story, 625.

${ }^{17}$ Barnett, Eyewitness to a Genocide, 174.

${ }^{18}$ Beardsley Interview, April 30, 2013; Emily Willard, “The Rwanda Sitreps," Electronic Briefing Book no. 455, Washington, DC: National Security Archive, February 3, 2014, accessed March 28, 2017, http://nsarchive.gwu.edu/NSAEBB/ NSAEBB455/.

${ }^{19}$ Prunier, The Rwanda Crisis, 192-195.

${ }^{20}$ Roméo Dallaire. Shake Hands with the Devil: The Failure of Humanity in Rwanda (Toronto: Random House Canada, 2003); Emily Willard and Jake Freyer, "SITREPS detail Rwanda's Descent into Genocide 1994," Electronic Briefing Book no. 466, Washington, DC: National Security Archive, April 7, 2014, accessed March 28, 2017, http://nsarchive.gwu.edu/ NSAEBB/NSAEBB466/.

${ }^{21}$ Code Cable (fax) from Gen. Romeo Dallaire to Maurice Baril, UN DPKO, “Most Immediate," Washington, DC: National Security Archive, January 11, 1994, accessed December 9, 2018, https://nsarchive2.gwu.edu/NSAEBB/NSAEBB452/ docs/doc03.pdf; Des Forges, Leave None to Tell the Story, 150.

${ }^{22}$ National Security Archive, “International Decision-Making in the Age of Genocide: Rwanda 1990-1994, Annotated Transcript, Day 1," Washington, DC: National Security Archive and U.S. Holocaust Memorial Museum, June 2, 2014,
} 
Tensions continued to mount through the late winter and spring of 1994, erupting with the shooting down of a plane carrying Rwandan President Juvenal Habyarimana and Burundian President Cyprien Ntaryamira on April 6, 1994. That evening and the next day, April 7, Hutu extremists and Rwandan government forces started targeting Tutsi and moderate Hutu politicians, murdering them and their families in their homes. Soon, all Tutsis and moderate Hutus civilians became targets, leading to mass executions, torture, rape, and massacres of men, women, and children across Rwanda. Foreign governments, such as the United States, France, and Belgium quickly shut down embassies, and evacuated personnel and all their civilians, abandoning thousands of Rwandans to the fate of bands of Interahamwe, a Hutu militia, armed with machetes.

When ten Belgian peacekeeping troops were killed on the first day of the genocide, Belgium initially requested reinforcements, and many members of the UNSC called for an expansion of UNAMIR's mandate and to send reinforcements. On April 15, the United States representative to the UN dropped "a bombshell" on the UN Security Council calling for the full withdrawal of UNAMIR troops, despite a strong movement among non-aligned countries on the UNSC to extend the mandate and send reinforcements. ${ }^{23}$ Weeks into the genocide on April 21, the UNSC passed a resolution to withdraw the majority of UNAMIR troops, leaving a "skeletal staff" of 270 down from approximately 2,500. ${ }^{24}$ Further clarity is needed: How did the United Nations Security Council come to this decision to withdraw UNAMIR troops? What role did the United States play and why?

\section{Research Methodology}

This study utilized qualitative research methods of analysis of declassified U.S. government records, semi-structured oral history interviews, shorter reflective interviews, and a type of participatory action research known as "critical oral history." The author conducted this research between January 2013 and December 2016 which consisted of conducting oral history interviews with key stakeholders, submitting Freedom of Information Act (FOIA) and Mandatory Declassification Review (MDR) requests, and analyzing declassified documents. Additionally, the author was a participant-observer at the June 2014 critical oral history conference. ${ }^{25}$

In preparation for the critical oral history conference, the National Security Archive and U.S. Holocaust Memorial Museum filed a Mandatory Declassification Review (MDR) request with the Clinton Presidential Library ${ }^{26}$ in November 2013 for a series of approximately 120 NSC documents. We identified the series of 120 documents out of lists of thousands of documents that were withheld under the B1 exemption in prior FOIA cases with the Library. The lists contained the date, office, and title of most of the documents, and the research team prioritized specific dates, titles, and incidents, often-times guessing due to lack of information. After a year and a half of multiple levels of bureaucratic review processes and sign-offs, including Obama administration officials at the White House, approximately 550 pages were released publicly on the Clinton Presidential Library website over several days starting on April 7, 2015. ${ }^{27}$ A selection of the released documents

94-97, accessed December 9, 2018, https://nsarchive2.gwu.edu/NSAEBB/NSAEBB508/docs/Rwanda\%20Final\%20 Transcript $\% 20 \mathrm{Day} \% 201 . \mathrm{pdf}$. The scope of this paper does not include a detailed look into the international response to Gen. Dallaire's "genocide fax," however this topic was extensively discussed in the first day of this conference, the transcript of which is available in the link above.

${ }^{23}$ Cable USUN 1588 from U.S. Mission to the U.N to U.S. Secretary of State, “TFRWOL: US Drops Bombshell on Security Council - 4/15," Electronic Briefing Book no. 511, Washington, DC: National Security Archive, April 15, 1994, accessed June 4, 2018, https://nsarchive2.gwu.edu/NSAEBB/NSAEBB511/docs/DOCUMENT 16.pdf.

${ }^{24}$ Blanton and Willard, 1994 Rwanda Pullout.

${ }^{25}$ It is not within the scope of this research paper to thoroughly analyze additional resources such as the Belgian senate hearings, and official reports from United Nations, Organization of African Unity, Belgian Senate, and U.S. State Department. It is the focus of this paper to report on the results of the June 2014 conference and recent declassification efforts of U.S. government records.

${ }^{26}$ The Clinton Presidential Library is part of the National Archives and Records Administration (NARA).

${ }^{27}$ The document releases are available from the Clinton Presidential Library at the following URLs: https://clinton. presidentiallibraries.us/items/show/36587; https://clinton.presidentiallibraries.us/items/show/36636; https://clinton. presidentiallibraries.us/items/show/36616. The author thanks the archivists at the Clinton Presidential Library, and National Archives and Records Administration for their extensive work and cooperation on this request, and the 
along with initial analysis are available in the National Security Archive electronic briefing book, "1994 Rwanda Pullout Driven by Clinton White House, U.N. Equivocation" published on April 16, $2015 .^{28}$ The twentieth anniversary of the genocide and the preparation for the conference provided the key catalyst to push for this release of documents, however this collection of documents were not released until nearly a year after the June 2014 conference, and are thus not a subject of the conference conversation.

Critical oral history is a participatory action research method developed by James Blight and janet Lang, which brings together former high-level government decision makers to discuss how they made key policy decisions, drawing upon the declassified documents the officials created as reference points to frame and direct the conversation. Scholars analyze the documents and pose questions to the former officials regarding specific policy decisions and chronology of events. This builds on traditional archival and oral history research because the conversation among the participants and scholars often bring to light new information about how policies and documents are created, and how decisions were made. ${ }^{29}$

The documents bring evidence directly into the conversation and prevents merely a recollection or discussion about past events, but pushes participants to answer for past actions, decisions, and writings. Ann Stoler writes that, "whether documents are trustworthy, authentic, and reliable remain pressing questions, but a turn to the social and political conditions that produced those documents...has altered the sense of what trust and reliability might signal and politically entail." 30 The critical oral history methodology illuminates the specific contexts, motivations, and informal conversations during which key policy decisions are often made, though not recorded in official documents, often advancing scholarship to new understandings of long-researched historical topics. ${ }^{31}$ Stoler argues for the importance of "critically reflecting on the making of documents and how we choose to use them...not as sites of knowledge retrieval but as sites of knowledge production." 32 Critical oral history conferences can provide the space to produce conversations of critical reflection and lead to new knowledge production.

The convening of a critical oral history conference is often the first time that officials from different countries and intuitions are brought together since the time the events took place, or possibly the first time they are ever meeting in one room together. These conferences can often be the place where former officials find healing and reconciliation in light of past events, however they can also bring back painful, traumatic memories. ${ }^{33}$ Coinciding with the twentieth anniversary of the Rwandan genocide, the conference created a space and an opportunity to push for additional declassification of government records, building upon extensive work from previous research projects and declassification efforts. ${ }^{34}$ As officials were invited, they were inspired and encouraged to bring declassified documents from their own governments, some of which were included in the conference briefing books. Conference attendees provided documents from New Zealand, the United Kingdom, and the Czech Republic. ${ }^{35}$ Prudence Bushnell provided a personal notebook from

larger declassification efforts associated with this project.

${ }^{28}$ Blanton and Willard, 1994 Rwanda Pullout.

${ }^{29}$ James Blight, et al., Becoming Enemies: U.S.-Iran Relations and the Iran-Iraq War, 1979-1988 (Lanham: Rowman \& Littlefield Publishers, 2012).

${ }^{30}$ Ann Laura Stoler. "Colonial Archives and the Arts of Governance: On the Content in the Form," In Archives, Documentation, and Institutions of Social Memory: Essays from the Sawyer Seminar, ed. by Francis X. Blouin and William G. Rosenberg (Ann Arbor: University of Michigan Press, 2006), 268.

${ }^{31}$ For example see: James Blight and janet Lang, Dark beyond Darkness: The Cuban Missile Crisis as History, Warning, and Catalyst (Lanham: Rowman \& Littlefield, 2018).

${ }^{32}$ Stoler, Colonial Archives, 268.

${ }^{33}$ Author's informal conversations with conference participants, The Hague, Netherlands, June 2014.

${ }^{34}$ The International Criminal Tribunal on Rwanda archives and proceedings (http://ictrcaselaw.org/); Will Ferrogiario's FOIA research at the National Security Archive (https://nsarchive2.gwu.edu//NSAEBB/NSAEBB117/index.htm); the United Nations, Belgian, and French government reports, the Mitterand Archive (http://www.mitterrand.org/-Lesarchives-.html), and the U.S. Department of State collections.

${ }^{35}$ Michael Dobbs, "Inside the UN Security Council: April-July 1994," Electronic Briefing Book no. 472, Washington, DC: National Security Archive, June 2, 2014, accessed December 9, 2018, https://nsarchive2.gwu.edu/NSAEBB/ 
the time, and several other attendees brought additional primary and secondary material such as publications, working papers, and reports to circulate. ${ }^{36}$

The National Security Archive, United States Holocaust Memorial Museum, and The Hague Institute for Global Justice convened a critical oral history conference on the Rwandan genocide in June 2014 in The Hague, the Netherlands titled, "International Decision-Making in the Age of Genocide: Rwanda 1990-1994." Conference organizers invited 35 former officials, high level decision-makers, journalists, and scholars, representing 14 countries and the United Nations. Participants included UNAMIR Force Commander Roméo Dallaire and his deputy Henry Anyidoho, genocide survivor and civil society leader Monique Mujawamariya, Médecins sans Frontiéres (MSF) representative Dr. Jean-Hervé Bradol, journalists such as Colette Braeckman and Jean-Philippe Ceppi, and renowned Rwanda genocide scholars and academics such as Linda Melvern, Andre Guichaoua, and Michael Barnett, among others. The critical oral history portion of the conference took place over two days and was ordered chronologically and broken into thematic segments. The participants were given bound copies (briefing books) of 160 declassified documents to reference during the conference. The conference briefing books were prepared by researchers after extensive analysis of the documents which were chosen based on themes and chronology of events to be covered during the conference discussions. Simultaneous interpretation was provided in both English and French. The conference was audio taped and transcribed, and a rapporteur's report, the document collections and an annotated, edited transcript were published electronically in April 2015. ${ }^{37}$

\section{United States Opposition to UNAMIR from the Beginning}

The United States' decision to oppose the implementation of UNAMIR in the fall of 1993 was part of a larger shift in U.S. foreign policy at the time, away from supporting peacekeeping missions due to the political context at the time, and the crisis in Somalia was the perfect opportunity that policymakers were looking for to obtain public support for limiting UNAMIR's mandate. Existing scholarship points to this broad policy change, and its implications in the United States' policy in autumn 1993, however other research and former officials place an emphasis of the Somalia crisis as the main reason for the policy shift. ${ }^{38}$ Grünfeld and Huijboom write that "after Somalia, the Republican Party wanted the United States to get less involved in the peacekeeping missions of the United States, which was shown in the development of PDD-25." ${ }^{39}$ At the critical oral history conference in June 2014, Ambassador John Shattuck explained that "the hangover with Somalia produced a new peacekeeping directive, Presidential Decision Directive 25, which came out in early May 1994." 40

However, recently released documentation supports the argument that the United States' apprehension to supporting UNAMIR from the beginning was part of the larger trend in U.S. peacekeeping prior to the Somalia crisis, not as a result of the Somalia crisis. To be sure, this article does not go as far to claim that the Somalia crisis had very little impact on U.S. policy at the time, as one recent study claims. ${ }^{41}$ The killing of U.S. troops in Somalia certainly had a chilling effect on

\section{NSAEBB472/.}

${ }^{36}$ Emily Willard, "Key Diplomat's Personal Notebook Sheds Light on Inner Workings of US Government Response to Genocide Unfolding in Rwanda in 1994," Electronic Briefing Book no. 500, Washington, DC: National Security Archive, January 30, 2015, accessed December 9, 2018, https://nsarchive2.gwu.edu/NSAEBB/NSAEBB500/; Karel Kovanda, "The Czech Republic on the UN Security Council: The Rwandan Genocide," Genocide Studies and Prevention: An International Journal 5, no. 2 (2010), 192-218.

${ }^{37}$ Conference materials including the briefing book, transcripts, interviews, conference report, and list of participants and staff are available on the conference website hosted by the National Security Archive, accessed May 18, 2018, https:// nsarchive2.gwu.edu/ageofgenocide/ and the U.S. Holocaust Memorial Museum, accessed June 4, 2018, available from: https://www.ushmm.org/confront-genocide/speakers-and-events/all-speakers-and-events/rwanda-conference.

${ }^{38}$ Shattuck, Freedom on Fire; Barnett, Eyewitness to a Genocide; Grünfeld and Huijboom, The Failure to Prevent; Kroslak, The French Betrayal.

${ }^{39}$ Grünfeld and Huijboom, The Failure to Prevent, 142.

${ }^{40}$ National Security Archive, International Decision-Making, Day 1, Annotated Bibliography, 120.

${ }^{41}$ Gasbarri, Revisiting the Linkage. 
U.S. policy towards peacekeeping, and greatly informed the PDD-25 final document, however it was not the central factor in causing this policy change; it provided more reasons for the United States to continue strengthening the policy. The following section will explore the broader shift in U.S. policy towards peacekeeping, as well as how this policy played out in a debate between the NSC and Department of State regarding support for UNAMIR, both before and after the killing of U.S. troops in Somalia in early October 1993.

Change in United States Peacekeeping Policy

The development of U.S. policy changes concerning peacekeeping operations is an example of policy that sheds light on United States' decision-making process. We see the existence of tension in power relations between the NSC and Department of State in that the NSC led the policy shift away from involvement in peacekeeping, and this shift was often in conflict with information and policies coming from the Department of State. ${ }^{42}$ Former Deputy Assistant Secretary of State for African Affairs, Prudence Bushnell described that the prevailing political climate leading up to the Somalia crisis in early October 1993 created the context for whether the United States would support UN peacekeeping troops in Rwanda and minimize existing ones. ${ }^{43}$ Bushnell explained that President Clinton won the presidential election in 1992 and was inaugurated in January 1993 with a strong platform of economic reform. The post-Cold War foreign policy and domestic political pressures about the economy called for the opening of new embassies in former soviet bloc states, but without spending more money ${ }^{44}$ At the time the U.S. was debating the future of the Rwanda peacekeeping mission, the Department of State was "looking for money to fund the new embassies," so the agency made the choice to make cuts to missions in African countries, explained Bushnell. This resulted in tension in the Department of State as the government was "in the process of moving out, closing down AID programs, [and] closing down...CIA stations." ${ }^{45}$ Bushnell's job was to "postpone the decision to cut off funding, or the other way is just get a little bit of funding" and that she was relieved that "at least the door was open to a peacekeeping operation." 46 U.S. foreign policy had already begun to shift in 1993, and Department of State officials like Prudence Bushnell felt the political pressures for the United States to disengage from peacekeeping missions, especially in Africa. United States support for peacekeeping missions "became an even harder sell in October '93" after to Somalia crisis. ${ }^{47}$ Even prior to the Somalia crisis, officials in the NSC were struggling to find a way forward amid the lack of resources.

Tony Lake, National Security Advisor at the time, explained that in Clinton's late September 1993 speech to the U.N., "the president began by calling for stronger peacekeeping operations by the U.N. -- not say no, but learning how more effectively to say yes...In other words, to make the U.N. more effective in all this, but at the same time, to recognize that you have to make choices, that the U.N. cannot do everything." ${ }^{48}$ This policy shift is evident in the Department of State documents where there is an effort to support the peace process in Rwanda, however the documents also show the pushback from the NSC, particularly Richard Clarke who is looking for opportunities to say "no."

In a newly released document dated August 2, 1993 from Susan Rice, a member of NSC peacekeeping staff in 1993 and 1994, to Tony Lake described the challenges facing United States support of peacekeeping at the time, even prior to the Somalia crisis in early October $1993 .{ }^{49}$ She

${ }^{42}$ Hook, Domestic Obstacles to International Affairs, 23.

${ }^{43}$ Prudence Bushnell, Interview by Michael Dobbs, Genocide Prevention Project, November 22, 2013, Washington DC: U.S. Holocaust Memorial Museum.

${ }^{44}$ Ibid.

${ }^{45}$ Ibid.

${ }^{46}$ Ibid.

${ }^{47}$ Ibid.

${ }^{48}$ Tony Lake, Interview by PBS Frontline, Frontline, December 15, 2003, accessed October 17, 2018, https://www.pbs.org/ wgbh/pages/frontline/shows/ghosts/interviews/lake.html.

${ }^{49}$ National Security Council Memorandum from Susan Rice to Tony Lake, “Five Imminent New UN Peacekeeping Operations," Electronic Briefing Book no. 511, Washington, DC: National Security Archive, August 2, 1993, accessed 
wrote that while the United States has "interest in resolving" the five upcoming peacekeeping operations, "we do not have funds to pay for them." She continues: "The reality is that the U.S. must begin immediately to make tough choices among new as well as existing operations, while we fight strenuously to obtain sufficient funds from congress and support from the American public" (emphasis original). Rice clearly explains the dilemma, indicating the interest in supporting the peacekeeping, citing the "strenuous" fight, but also the lack of political will in congress, and lack of public support. She identifies the specific financial concerns in "finding offsets to pay for new operations since obtaining brand new money is obviously unlikely in the near term." Rice cites the "current hostility among congressional appropriations to peacekeeping" particularly in "regions of little public interest" and indicates that "obtaining a budget amendment...could be difficult and require, at a minimum, high-level administration lobbying."

Rice explains that there are two main options the U.S. must choose from when facing these upcoming peacekeeping operations and what she cites as the United States' " $\$ 1$ billion" debt to U.N. peacekeeping: "voting for mission which we cannot pay for, or; vetoing resolutions because we lack sufficient funds." ${ }^{50}$ She sees that the first option is "irresponsible" because of the damage it would cause to U.N. infrastructure, but also sees the second option as concerning as other permanentfive (P5) member nations might follow suit. This document further illuminates explanations of the political climate leading up to the Rwanda genocide, even before the Somalia crisis as one that was generally moving away from United States involvement in peacekeeping, mainly due to economic concerns, and lack of public support, particularly from congress. ${ }^{51}$

Scholar Michael Barnett identified challenges the U.N. faced in a post-Cold War where powerful states such as the United States "were openly questioning the U.N.'s role in world politics." ${ }^{2} \mathrm{He}$ argues that this was then exacerbated by the crisis in Somalia and that the "United States scapegoated the U.N. for its own policy failures," causing a "positively poisons" relationship between the United States and the U.N. ${ }^{53}$ Barnett explained at the conference in June 2014, that U.S. lack of support for UNAMIR was "part of the broader climate... of that period...that the US [was] impoverishing the U.N.," and the United States was looking for any reason "to shut down the operation." ${ }^{54}$ The memo from Rice to Lake from August 2, 1993 clearly illustrates the pre-Somalia crisis lack of support for the U.N., which then became further constrained after Somalia, and continued through the genocide.

During the June 2014 conference, Former Assistant Secretary of State John Shattuck remarked that the political context in which the United States was moving away from humanitarian intervention "began to evolve very rapidly after the Somalia crisis." 55 The United States' involvement in and support of peacekeeping missions was being reevaluated, somewhat in response to the disaster in Somalia, explained Shattuck, but also a general "hardening of views in the U.S. Pentagon about peacekeeping operations." ${ }^{56}$ In his book, Shattuck explained that President Clinton was skeptical of the Department of Defense and Pentagon, never having served in the military. Prior to Somalia, the President's relationship "with the Pentagon brass were strained during the early period of his presidency" due to "the question over his draft service and his handling of the issues of gays in the military." 57 By renegotiating the United States' stance on peacekeeping missions globally and placing strict requirements on U.S. involvement, as outlined in PDD-25, President Clinton hoped to gain more credibility with the defense agencies. Shattuck explained that as the architect

October 10, 2018, https://nsarchive2.gwu.edu/NSAEBB/NSAEBB511/docs/2014-0278-M 19930802.pdf. When the author indicates the document is "newly released," it is from the collection of records released by the Clinton Presidential Library in April 2015, described in the methodology section of this paper.

${ }^{50}$ Ibid.

${ }^{51}$ Shattuck, Freedom on Fire, 34.

${ }^{52}$ Barnett, Eyewitness to a Genocide, 162-163.

${ }^{53}$ Ibid., 163.

${ }^{54}$ National Security Archive, International Decision-Making, Day 1, Annotated Transcript, 119.

${ }^{55}$ Ibid., 21.

${ }^{56}$ Ibid., 22.

${ }^{57}$ Shattuck, Freedom on Fire, 26. 
of PDD-25, NSC advisor Richard Clarke was attempting to save U.S. involvement in peacekeeping by preventing further tragedies which would make the United States even less likely to support future operations.

Clarke was the lead in creating the new, more limited U.S. policy toward humanitarian intervention and peacekeeping, and as the documents show, had considerable influence on the final decision-making on the U.S. support for non-intervention. ${ }^{58}$ Samantha Power wrote that "what is most remarkable about the American response to the Rwandan genocide is not so much the absence of U.S. military action as that during the entire genocide the possibility of U.S. military intervention was never even debated. ${ }^{\prime 59}$ Power's assertion is logical because the NSC was looking to drawdown the Rwandan peacekeeping operation from the very beginning, and U.S. intervention would thus have never debated once the genocide started because of political pressures to reduce U.S. peacekeeping. While the killing of U.S. troops in Somalia certainly had an impact on the United States' decision to only reluctantly support UNAMIR, these new documents point to a more complex narrative of policy at the time, rather than seen as a predominantly defensive action to withdraw support for peacekeeping operations in reaction to the Somalia crisis, which many scholars and former U.S. officials favor. ${ }^{60}$ These documents support the argument of some scholars and former officials that see the United States' resistance to UNAMIR as part of a larger context of change in U.S. policy on peacekeeping, which was exacerbated by, but existed prior to, the Somalia crisis. ${ }^{61}$

Internal Debate over Support for UNAMIR

This broader change in peacekeeping had a clear impact on the discussion within the State Department, and within the NSC, as well as a debate between the two organizations prior to the Somalia crisis in early October 1993. This debate between the NSC and Department of State also shows the tension between the two offices over the final say on U.S. foreign policy-making.

In a newly released document from September 28, 1993, U.S. representative to the United Nations (USUN), Madeleine Albright reported that the Rwandan peacekeeping operation (PKO) "is one of the better-organized PKOs we have seen" writing that it clearly fits the six points of criteria discussed that would guide U.S. policy toward supporting PKOs. Two days later on September 30, a U.S. intelligence assessment reported that "the United Nations peacekeeping plan for Rwanda has excellent prospects for success" and warned that "failure to provide a peacekeeping force" would be "adverse to U.S. interests." ${ }^{2}$ The intelligence assessment went on to say that in the case of UNAMIR in Rwanda, "support of UN operations should be inexpensive, uncomplicated, and far less demanding than the PKOs...elsewhere in Africa." ${ }^{63}$ High levels of the U.S. government not only expected UNAMIR to be a success, but failure to support UNAMIR would result in "increased regional instability" and a "breakdown of the peacekeeping process." ${ }^{64}$ It seemed as though U.S. support for the peacekeeping mission would be clear. However, members of the NSC had already made up their minds that UNAMIR was not worth supporting. ${ }^{65}$

In a newly released Department of State cable from September 29, 1993 from USUN to the Secretary of State in Washington, D.C., Albright wrote that "Dick Clarke intimated that Rwanda may be the case the NSC is looking for to prove that the US can say "no" to a new peacekeeping

\footnotetext{
${ }^{58}$ Power, A Problem from Hell, 364.

${ }^{59}$ Ibid., 367.

${ }^{60}$ Kroslak, The French, 207-208; Adelman and Suhrke, Early Warning and Response, 303.

${ }^{61}$ Barnett, Eyewitness to a Genocide, 162-163; Lake, Interview by PBS Frontline.

${ }^{62}$ Secret Memorandum, “Assessment: Peacekeeping Operations in Rwanda," Electronic Briefing Book no. 511, Washington, DC: National Security Archive, September 30, 1993, accessed June 4, 2018, https://nsarchive2.gwu.edu/NSAEBB/ NSAEBB511/docs/DOCUMENT\%203.pdf.

${ }^{63} \mathrm{Ibid}$.

${ }^{64}$ Ibid.

${ }^{65}$ Cable USUN 4735 from Madeleine Albright U.S. Mission to the U.N. to U.S. Secretary of State, "Rwanda and Criteria for New UN PKO," Electronic Briefing Book no. 511, Washington, DC: National Security Archive, September 28, 1993, accessed June 4, 2018, https://nsarchive2.gwu.edu/NSAEBB/NSAEBB511/docs/DOCUMENT\%201.pdf.
} 
operation." ${ }^{66}$ Despite the intelligence assessment from September 30, NSC advisor Tony Lake, Richard Clarke and aide Susan Rice wrote in an October 1, 1993 email "while this operation may have a better of success than some others, the Security Council vote [on UNAMIR's mandate] comes at a difficult moment for us given our stated reluctance to say 'yes' to every proposed operation." 67 Cleary, the NSC's opposition to UNAMIR was not simply a reaction to the Somalia crisis which would erupt into the killing of 18 U.S. soldiers two days later on October $3,1993 .{ }^{68}$ Additionally, this opposition went against government intelligence which supporting UNAMIR would be in the national interest of the United States, showing a disagreement between NSC and Department of State on policy towards UNAMIR.

It is important to note these two different, but concurrent lines of thinking. The Department of State had high hopes for the success of UNAMIR and saw that a successful mission would be crucial for promoting regional stability. At the same time, we see a more general concern from the NSC about the difficult economic and political situation the U.S. faced in developing peacekeeping policy, as we see in Rice's August 1993 memo. In a 2003 interview with PBS, former Assistant Secretary of State for African Affairs George Moose explains that he had received "guidance" from "senior people in the administration" to support the Rwanda peace processes because it "had great potential, not only for Rwanda, but the entire region." ${ }^{169}$ He continued by explaining there was certainly concerns from within the NSC, parts of the Department of State, and the Department of Defense about "about adding yet another major peacekeeping operation to a very long list of peacekeeping operations we had in Africa alone." He explains that there were not only concerns in the Clinton administration, but also in congress: "[it was] a burden about cost, a question about how you justify and rationalize all this to the appropriators and the committees on the Hill, many of whom didn't think we needed to be there at all." ${ }^{70}$ There was strong resistance to support any new peacekeeping mission, including Rwanda specifically due to economic issues and lack of political will.

This tension between different parts of the government was discussed during the June 2014 conference. Scholar Michael Barnett, who was working for the U.N. at the time of the genocide explained his viewpoints on the state of U.S. policy in 1993 and leading up to the genocide in early 1994. Shattuck spoke to the tension among different parts of the U.S. government, in response to remarks by Barnett:

I do not think there was a unified position within the U.S. government that we had to pick off peacekeeping operations and shut them down. I think there were parts of the U.S. government that had a different position, the State Department in particular. President Clinton had done a lot to contract out certain U.S. activities and obligations to the UN. There was an ambivalence in the U.S. government about peacekeeping. ${ }^{71}$

We see this lack of a unified position between the Department of State and the NSC, particularly around this issue of whether or not to approve the peacekeeping mission for Rwanda.

Despite the NSC's opposition, on October 5, 1993, the UNSC authorized UNAMIR with reluctant support from the United States, commissioning 2,548 U.N. troops to the mission in

\footnotetext{
${ }^{66}$ Cable State 297511 from U.S. Secretary of State to U.S. Mission to the U.N., “Evening Notes 9/28," Electronic Briefing Book no. 511, Washington, DC: National Security Archive, September 29, 1993, accessed June 4, 2018, https://nsarchive2. gwu.edu/NSAEBB/NSAEBB511/docs/DOCUMENT\%202.pdf.

${ }^{67}$ Memorandum from Richard Clarke and Susan Rice to Tony Lake, "Draft Message to General Quesnot on Rwanda Peacekeeping," Washington, DC: National Security Archive, October 1, 1993, accessed June 4, 2018, https://nsarchive2. gwu.edu/NSAEBB/NSAEBB511/docs/DOCUMENT\%204.pdf.

${ }^{68}$ Barnett, Eyewitness to Genocide, 37.

${ }^{69}$ Moose, Interview by PBS Frontline.

${ }^{70} \mathrm{Ibid}$.

${ }^{71}$ National Security Archive, International Decision-Making, Day 1, Annotated Transcript, 120. Shattuck's response to Barnett's views on the state of U.S. government policy making regarding peacekeeping in 1993 and early 1994, see full conversation on pages 118 to 121 in the annotated transcript mentioned earlier in this footnote.
} 
Rwanda. ${ }^{72}$ While the aftermath of the killing of U.S. troops and the graphic images of them being dragged through the streets certainly had an impact on U.S. foreign policy, the United States' opposition to UNAMIR was not simply a reaction to the Somalia crisis. The policy stance was the result of a growing political climate to move to decrease the United States' role in international humanitarian intervention.

The disagreement among U.S. agencies about intervention in Rwanda and the "lack of trust" in the Department of State is clear in these documents. Steven Hook wrote that this lack of trust results in a situation where "the State Department is routinely neglected in each of its primary areas of responsibility: the development and articulation of foreign policy; the conduct of private and public diplomacy; and the transfer of foreign assistance."73 This tension between the NSC and the Department of State viewpoints influenced the United States' and subsequently the United Nations' final polices towards Rwanda, from the months leading up to, and throughout, the genocide. The United States had a strong voice in putting limits on UNAMIR's mandate in order to minimize the likelihood of a military or expanded intervention, affecting the capabilities of Dallaire on the ground in Rwanda. As the UNSC debated the funding and mandate of the would-be peacekeeping operation, Dallaire recalled during the June 2014 conference that he was frustrated by "the impossible scenario of reducing [his] troop level request even before [he] started to deploy." 74 Prudence Bushnell, former Deputy Assistant Secretary of State for African Affairs explained that "UNAMIR was dead on arrival."75

As evidence presented shows, the larger political context of U.S. policy to move away from supporting peacekeeping operations prior to the Somalia crisis. The tension among agencies in the U.S. government about this policy clearly influenced the U.S. stance on Rwanda throughout the peace process and ensuing genocide. This policy stance eventually led to the decision to call for a withdrawal of UNAMIR in April 1994. This shift in policy had consequences leading to an underfunded UNAMIR, which eventually contributed to Rwanda's descent into genocide, and the failure of the international community to respond to stop the violence.

\section{United States in the Driver's Seat}

The United States' move to reduce support for peacekeeping fueled the U.S. government's strategy and efforts to limit and "pull the plug" on UNAMIR. This course of action in opposition to the peacekeeping operation continued unabated even with the start of the genocide on April 7, 1994. Looking closely at the international community's decision to withdraw UNAMIR troops provides a clearer understanding of the making of U.S. foreign policy, as well as international decisionmaking in the U.N. Evidence from newly declassified documents and conversations from the June 2014 critical oral history conference provide further illumination to what was going on behind the scenes in the first weeks of the genocide, further clarifying the central role of the United States in pushing to call for a withdraw of UNAMIR troops in April 1994. ${ }^{76}$

Existing literature and former officials paint the picture of the decision to withdraw UNAMIR peacekeeping troops as Belgium's defensive reaction to the killing of their 10 peacekeeping troops, and the United States call for withdrawal as a symptom of suffering from "Somalia syndrome."77 Other research considers a more complicated series of events, challenging the oversimplification of Belgium's role in the withdrawal of UNAMIR troops. Grünfeld and Huijboom write, "many authors, political and military leaders indeed have interpreted the Belgian role in this way with

\footnotetext{
${ }^{72}$ Des Forges, Leave None to Tell the Story, 130.

${ }^{73}$ Hook, Domestic Obstacles to International Affairs, 23.

${ }^{74}$ National Security Archive, International Decision-Making, Day 2, Annotated Transcript, 24.

${ }^{75}$ Ibid., 29.

${ }^{76}$ It is understood that many other factors where at play, such as French, UK, and other Security Council members (permanent and rotating) government interests, and politics within the United Nations, particularly in the Security Council, however the scope of this paper is limited to the results of this research project, and a focus on the role of the United States.

${ }^{77}$ Kroslak, The French Betrayal, 50-51, 207-208, 210; Adelman and Suhrke, Early Warning and Response, 300; Shattuck, Freedom on Fire, 25-26, 34; Boutros-Ghali, Interview by PBS Frontline.
} 
some disgust, making Belgium an easy scapegoat for a world-wide failure to prevent the genocide in Rwanda." ${ }^{\prime 78}$ New evidence supports the argument that UNAMIR troop withdrawal was not simply Belgium's defensive reaction to the killing of ten of their peacekeeping troops. Documents show that pressure from the United States via the NSC to find a reason to pull back on peacekeeping missions resulted in stonewalling the U.N. Security Council despite well-organized Non-Aligned Movement (NAM) efforts to expand the UNAMIR mandate and send reinforcements. In a puzzling move, Belgium switched from calling for reinforcements to calling for a full withdrawal, lobbying strongly for other governments to join them. ${ }^{79} \mathrm{Within}$ the U.S. government tension mounted between the NSC and Department of State regarding who makes the final call on U.S. decision-making about the future of UNAMIR in early April 1994. This incident clearly shows how eventually, the NSC made the final call on U.S. foreign policy to call for the withdrawal of peacekeeping troops as the genocide in Rwanda raged on. The following section will explore the debate within the United States government and its actions within the U.N. regarding the decision to withdraw UNAMIR, as well as the aftermath of this decision, both in the U.N., and on the ground in Rwanda.

To Withdraw UNAMIR or Not?

Madeleine Albright, U.S. representative to the U.N. at the time, wrote that the U.S. decision to withdraw was largely a response to the Belgian request to the U.S. to support its decision to withdraw the UNAMIR troops. ${ }^{80}$ Power explained that the U.S. responded to Belgian requests to provide "cover" and "support for a full U.N. withdrawal." ${ }^{81}$ It was less of the United States wanting to help out Belgium, and more that the NSC saw an opportunity to pull out which it had been looking for since before day one. Melvern wrote that the United Kingdom and the United States were set on the conclusion that the peacekeeping mission was no longer functioning under its current mandate, and that the two nations were "considering whether or not to pull out UNAMIR completely. ${ }^{82}$ A newly released document from April 9, 1994 shows that the NSC was pushing "to terminate [the] U.N. mission," because as NSC official Richard Clarke explained, the mission is "not working" and should be withdrawn. ${ }^{83}$ He continues, "we make a lot of noise about terminating U.N. forces that aren't working. Well, few could be as clearly not working. We should work with the French [sic] to gain a consensus to terminate the U.N. mission."

The United States consistently refused any expansion in mandate or force size, in a continuation of the policy of the preceding six months. The killing of the Belgian troops was a convenient reason to further U.S. policy to pull support for the Rwanda peacekeeping mission. As mentioned previously, Clarke was looking for a reason to "say no" to UNAMIR, and this time his efforts were successful..$^{84}$ U.S. and U.N. officials ignored requests from Dallaire and his second in command, Henry Anyidoho, leaving the peacekeepers confused and lacking desperately needed support: "The normal practice is that if you are in an emergency situation, and you come under pressure, you are reinforced" explained Anyidoho. ${ }^{85}$ Nigeria's representative Ibrahim Gambari found it "baffling that at a time of crisis, by act of omission or commission, the council supported the reduction option." 86

Meanwhile, the NAM caucus in the UNSC vociferously called for reinforcements for UNAMIR

\footnotetext{
${ }^{78}$ Grünfeld and Huijboom, The Failure to Prevent, 196.

${ }^{79}$ Ibid.; National Security Archive, International Decision-Making, Day 2, Annotated Transcript, 19-21; Melvern, A People Betrayed, 162.

${ }^{80}$ Madeleine Korbel Albright, Madam Secretary (New York: Miramax Books, 2003), 150-151.

${ }^{81}$ Power, A Problem from Hell, 366-367.

${ }^{82}$ Melvern, A People Betrayed, 139.

${ }^{83}$ Memorandum from Richard Clarke to Donald Steinberg, "Rwanda: Next Steps for Sunday and Beyond," Electronic Briefing Book no. 511, Washington, DC: National Security Archive, April 9, 1994, accessed June 4, 2018, https:// nsarchive2.gwu.edu/NSAEBB/NSAEBB511/docs/DOCUMENT\%209.pdf.

${ }^{84}$ Cable State 297511, Evening Notes 9/28; Memorandum, Draft Message to General Quesnot on Rwanda Peacekeeping.

${ }^{85}$ National Security Archive, International Decision-Making, Day 2, Annotated Transcript, 16.

${ }^{86}$ Ibid., 18.
} 
and an expansion of its mandate. ${ }^{87}$ The NAM caucus led by Nigerian permanent representative to the U.N. Ibrahim Gambari wrote a non-paper making the argument for expansion and was supported by the permanent representatives of New Zealand and the Czech Republic, Colin Keating and Karel Kovanda, respectively. Gambari explained that "The Africans on the Council, Djibouti and Nigeria, supported of course by Brazil and the Czech Republic, argued forcefully that the idea of cutting and running was totally unacceptable...there was a deliberate proposal to reduce and that was the option that was finally allowed." ${ }^{88}$ However, despite pressure from the NAM caucus, the United States maintained a firm stance in opposition to UNAMIR creating a chain reaction which then resulted in the United Nation's Secretary General to call for a full withdrawal of UNAMIR troops.

Through political maneuvering, the United States was able to obtain a group decision to withdraw UNAMIR, keeping in alignment with the consistent policy of opposition to international humanitarian intervention in Rwanda. The U.S.'s lobbying and refusal to reinforce UNAMIR resulted in the Belgian's withdrawal of its peacekeepers, leading the UNSC to call for a nearly full withdrawal of UNAMIR. ${ }^{89}$ Without reinforcements, Belgian officials felt that the threat to their peacekeepers was too great. Belgian Ambassador to Rwanda, Johan Swinnen explained that "it was difficult, if not impossible, to justify keeping Belgian troops in Rwanda any longer." ${ }^{\prime 90} \mathrm{He}$ explained that "the Belgian Minister [Willy Claes] would not have called for withdrawal if we could have rapidly revised the mandate to produce a stronger mandate for UNAMIR." ${ }^{91}$ Subsequently, without Belgian troops, officials at the United Nations felt that the entire UNAMIR force was no longer viable. In a letter to the UNSC, Secretary General Boutros-Ghali called for a withdrawal because without Belgian troops, "it will be extremely difficult for UNAMIR to carry out its tasks effectively." ${ }^{\prime 92}$ In this case, because the U.S. was so vehemently against the expansion of UNAMIR, Belgium was pressured to call for a pullout. Either UNAMIR need to be reinforced, or it would fail, and considering that a large number of the UNAMIR forces were Belgian, Brussels could no longer support the mission.

Once Belgium announced the withdrawal of its troops from UNAMIR, the U.S.'s public position moved from an opposition to the reinforcement of the peacekeeping mission to the public call for full withdrawal of UNAMIR. The NSC took the lead on formulating a public statement, as documented in notes from a top-level meeting of U.S. officials on April 11, 1994 in which Richard Clarke directs the International Organization office of the Department of State to draft the resolution to withdraw UNAMIR..$^{93}$ Prudence Bushnell, Deputy Assistant Secretary for African Affairs at the Department of State recorded in her personal notebook (made public in 2014), that the "NSC requested IO to draft resolution to pull UNAMIR" and recalled that the NSC request came from Richard Clarke. ${ }^{94}$

Madeleine Albright, U.S. permanent representative to the U.N. wrote in an April 12, 1994 cable, that "it is worth considering taking the lead in the Security Council to authorize the evacuation of the bulk of UNAMIR while leaving behind a skeletal staff." ${ }^{95}$ However, the NSC was set on calling for a full withdrawal. In a newly released document from April 14, Richard Clarke is quoted

\footnotetext{
${ }^{87}$ Barnett, Eyewitness to a Genocide, 105.

${ }^{88}$ National Security Archive, International Decision-Making, Day 2, Annotated Transcript, 18.

${ }^{89}$ Boutros-Ghali, Interview by PBS Frontline.

${ }^{90}$ National Security Archive, International Decision-Making, Day 2, Annotated Transcript, 19-20.

${ }^{91}$ Ibid.

${ }^{92}$ Cable NZUN 2430 from New Zealand Mission to the United Nations to Wellington, N.Z., "Security Council: Rwanda," Washington, DC: National Security Archive, April 13, 1994, accessed October 21, 2018, https://assets.documentcloud. org/documents/1392939/footnote-141-nzun-2430.pdf.

${ }_{93}$ Prudence Bushnell, Personal Notebook No. 3, “UNAMIR Troop Withdrawal,” Electronic Briefing Book no. 511, Washington, DC: National Security Archive, April 11, 1994, accessed June 4, 2018, https://nsarchive2.gwu.edu/ NSAEBB/NSAEBB500/docs/NB\%20Excerpt\%20-\%20UNAMIR\%20Troop\%20Withdrawal.pdf.

${ }^{94}$ Ibid.; Bushnell Interview, November 22, 2013.

${ }^{95}$ Cable USUN 1503 from Madeleine Albright U.S. Mission to U.N. to Secretary of State, “TFRWOL: Future of UNAMIR and French Roles in Rwanda," Electronic Briefing Book no. 511, Washington, DC: National Security Archive, April 12, 1994, accessed June 4, 2018, https://nsarchive2.gwu.edu/NSAEBB/NSAEBB511/docs/DOCUMENT\%2014.pdf.
} 
saying in a teleconference, "there will be a short delay while we seek a mechanism to terminate UNAMIR." ${ }^{96}$ When that decision was made, Bushnell said she knew "that we had just signed the death warrant of people." ${ }^{97}$

\section{United States "Drops Bombshell" Calling for a Full Withdrawal}

On April 14 the United States put the plan to publicly call for a full withdrawal into motion; however, there was heated disagreement between the Department of State and the NSC. United States Secretary of State Warren Christopher wrote in a cable that "the greatly changed circumstances in Rwanda have rendered untenable the continued presence of UNAMIR forces in the country. We support a rapid but orderly withdrawal of UNAMIR forces." 98 As the United States' public narrative shifted from being against an expansion of UNAMIR to a full withdrawal of the peacekeepers, Secretary Warren delivered instructions to the U.S. representative at the U.N. to "approach senior secretariat officials urgently" and gain support. The cable also instructed the U.S. embassy in Belgium to "urge the GOB [Government of Belgium] to make a similar approach to the SYG [Secretary General] or his senior representatives." ${ }^{\prime 99}$ The U.S. embassy in Paris was to "inform the French government of our position and seek support."100 The United States wanted to gain support from a coalition of nations in the Security Council to pull the peacekeeping troops. These records suggest that the United States requested support from Belgium to call for a full withdrawal, contrary to the prevailing idea that the United States responded to Belgium's request for support to withdraw the troops.

Belgian Foreign Minister Willie Claes spoke to both Czech and Argentine officials, notifying them of Belgian's pullout of UNAMIR, and recommending a full withdrawal of UNAMIR troops from Rwanda. ${ }^{101}$ Melvern described this lobbying by the Belgians as "a diplomatic blizzard."102 During the June 2014 conference, Nigeria's Ibrahim Gambari recalled that Belgium "had the right to decide to withdraw, but they went beyond withdrawing. They canvassed strongly to bring to an end UNAMIR entirely." ${ }^{103}$ He said, "I do not understand how they went from the position of calling for a strengthening in UNAMIR's mandate in February 1994 to completely bringing down UNAMIR, when a horrendous situation of genocide was going on." ${ }^{\prime 104}$ Karel Kovanda of the Czech Republic also recalled the morphing of Belgian policy from withdrawing its own troops to "intensive efforts to scuttle UNAMIR as a whole."105

Even after the murder of the 10 Belgian peacekeepers on April 7, Brussels was still calling for an expansion of UNAMIR on April 8. ${ }^{106}$ Then, by April 12, Brussels was lobbying hard, "the Belgians had spoken to USUN about this and expected shortly to send instructions to Belgian embassies in UNSC permanent member capitals to ask for speedy decision on this issue." 107 The Belgians had abruptly determined that the UNAMIR "should be suspended for the time being as it no longer corresponds to the circumstances on the ground." 108 The NSC was looking for a reason to withdraw UNAMIR, and the killing of Belgian troops provided the reason.

\footnotetext{
${ }^{96}$ Memorandum from MacArthur DeShazer to Tony Lake et al,, "Rwanda Update," Electronic Briefing Book no. 511, Washington, DC: National Security Archive, April 14, 1994, accessed June 4, 2018, https://nsarchive2.gwu.edu/ NSAEBB/NSAEBB511/docs/DOCUMENT\%2015.pdf.

${ }^{97}$ Bushnell Interview, November 22, 2013.

${ }^{98}$ Cable STATE 98085, TFRWO1: Approach to UN Secretariat on UNAMIR.

${ }^{99}$ Ibid.

${ }^{100}$ Ibid.

${ }^{101}$ Kovanda, The Czech Republic, 199.

${ }^{102}$ Melvern, A People Betrayed, 162.

${ }^{103}$ National Security Archive, International Decision-Making, Day 2, Annotated Transcript, 18.

${ }^{104}$ Ibid., 21.

${ }^{105}$ Ibid., 26.

${ }^{106}$ Power, A Problem from Hell, 332; Cable BRUSSE 03953, Claes asks SYG for change in UNAMIR mandate.

${ }^{107}$ Cable BRUSSE 04128 from U.S. Embassy Brussels to U.S. Secretary of State, “WGRWO1: More on Belgian Position on UNAMIR," Washington, DC: State Department Electronic Reading room, April 12, 1994.

${ }^{108}$ Ibid.
} 
During this time, the NAM caucus was launching a fierce argument in support of expanding UNAMIR. At the conference in June 2014, Nigerian permanent representative Ibrahim Gambari recalled the debate in the Security Council that day and explained that "There had never been an interest on the part of the [permanent members] ...or even to some extent the U.N. Secretariat, in taking very seriously the positions of the non-aligned movement or the Africans who, after all, are elected by the African constituencies to defend Africa's position. The Africans are closest to the events." 109 Gambari explained in frustration that even at a time when the NAM caucus was considered powerful with six votes, their views were not taken seriously. ${ }^{110}$

A newly released Department of State cable from April 15 titled "U.S. Drops Bombshell on Security Council" reported a member of the NAM caucus saying "while Belgian concerns are understandable, they should not dictate the Council on the future of UNAMIR. UNAMIR should not repeat not withdraw," but still gave instructions for Albright to call for a full withdrawal. ${ }^{111}$ Albright wrote in her autobiography that her orders read: "Our opposition to retaining a UNAMIR presence in Rwanda is firm...It is based on our conviction that the Security Council has an obligation to ensure that peacekeeping operations are viable...and that UN peacekeeping personnel are not placed or retained, knowingly, in an untenable situation." ${ }^{112}$ There was, however, disagreement within the U.S. government. Albright recalled that hearing Gambari's presentation of the NAM's arguments and draft resolution to expand UNAMIR's mandate and reinforce the troops encouraged her to rethink the United States' position. ${ }^{113}$ She considered that the U.S. was perhaps on the wrong side and that the U.S.'s stance was being seen as obstructionist. In a 2004 interview with PBS Frontline, Albright explained, "I had the instructions which made no sense at all." She left the meeting to go into the hall to phone Washington. Albright notes that while her orders officially came from the Department of State, she thought she "might be able to get faster action from the NSC." 114 "I decided not to call the State Department from whence my instructions really came, but the National Security Council, because they were dealing with this on a very imminent basis...they said... 'we're worrying about this, and these are your instructions.' I actually screamed into the phone. I said, 'they're unacceptable and I want them changed'," Albright explained. ${ }^{115}$ This reinforces the view that the NSC had "more impact on strategic and crisis decision making" than the Department of State. ${ }^{116}$

The United States' hard stance in opposition to UNAMIR continued to influence the Security Council's decisions. Once Albright received more flexible instructions, the Security Council was eventually able to pass a resolution on the fate of UNAMIR that decreased its mandate but did not fully withdraw the troops. In a recently released document from April 19, NSC official Eric Schwartz wrote to Susan Rice and Donald Steinberg at the NSC to report that Human Rights Watch was "pleading that we oppose a quick UNAMIR pull-out from Rwanda" and if pulled out, "the Rwandans will quickly become victims of genocide." ${ }^{117} \mathrm{He}$ asks, "Is this true? If so, shouldn't it be a major factor informing high-level decision-making on this issue? Has it been?" The Security Council passed a resolution on April 21 drawing down troops from around 2,000 to 270.

\footnotetext{
${ }^{109}$ National Security Archive, International Decision-Making, Day 2, Annotated Transcript, 17.

${ }^{110}$ Ibrahim Gambari, interview with the author, June 3, 2014, The Hague, Netherlands.

${ }^{111}$ Cable USUN 1588, TFRWOL: US Drops Bombshell on Security Council - 4/15. While this document contains redactions regarding U.S. actions at the April 15 UNSC meeting, declassified documents from the UN office of Peacekeeping Operations, as well as from the Czech Republic, New Zealand, and the United Kingdom explain what happened at the meeting. Comparison of documents available here: https://nsarchive2.gwu.edu/NSAEBB/NSAEBB511/panels.jpg.

${ }^{112}$ Albright, Madam Secretary, 150.

${ }^{113}$ Ibid.

${ }^{114}$ Ibid.

${ }^{115}$ Madeleine Albright, Interview by PBS Frontline, Frontline, February 25, 2004, accessed October 21, 2018, https://www. pbs.org/wgbh/pages/frontline/shows/ghosts/interviews/albright.html.

${ }^{116}$ Hook, Domestic Obstacles to International Affairs, 24.

${ }^{117}$ National Security Council Memorandum from Eric Schwartz to Susan Rice and Donald Steinberg, "Pull-out of UNAMIR," Washington, DC: National Security Archive, April 19, 1994, accessed December 9. 2018, https://nsarchive2. gwu.edu/NSAEBB/NSAEBB511/docs/2014-0278-M 19940419.pdf.
} 
General Henry Anyidoho, in command of 800 Ghanaians on the ground as part of UNAMIR, questioned the reduction of troops down to 270. He explained at the June 2014 conference, "We were also on the ground and did not show any indication of leaving Rwanda. We were still ready, doing our job, all over the country. So why 270 ?"118 Anyidoho and his troops remained in Rwanda after the resolution was passed, as Gambari pointed out, technically in violation of the UN Security Council decision on April 21. ${ }^{119}$ Anyidoho emphasized that in response to the drawdown: "we on the ground felt it went against all logic that in an emergency situation, instead of being reinforced, our force was reduced... It was as if the mission was being abandoned."120 Colin Keating, the permanent member from New Zealand explained at the June 2014 conference that "the only reason the authorized level went to 270 was because this was the only figure which the U.S. team in New York would accept."121

Eventually, the U.N. labored to assemble an intervention force. Barnett writes that "at this point, the United States government was alone in publicly denying that the killing in Rwanda constituted genocide and was virtually isolated in opposing intervention."122 A newly released May 16, 1994 memorandum for Executive Secretary of the NSC William Itoh, lays out the variety of options possible under the recently implemented PDD-25, making it clear that the United States will not support a strengthening of UNAMIR. ${ }^{123}$ In a recently released June 15 memo from Steinberg, regarding talking points for President Clinton, suggesting that "it would do the President well to stand up for himself and say that genocide has occurred in Rwanda. Period." 124 Steinberg continues, saying: "We have every reason to believe that [acts of genocide have] [genocide has] occurred in Rwanda, as defined under the 1948 convention" (brackets original). If asked about obligations, Steinberg notes, "The Genocide Convention does not impose a responsibility on the part of any government to take any specific action." 125

\section{Conclusion}

The United States formed a policy in opposition to UNAMIR as the United Nations Security Council Members debated its mission, and as discussed previously, Richard Clarke at the NSC determined it would fail from the beginning, despite other U.S. intelligence suggesting it was viable, and likely going to be a successful mission. The United States' lack of support for UNAMIR was present before the murder of U.S. troops in Somalia, where as existing scholarship argues that the main reason for the United States' lack of support for UNAMIR was in response to a drawback of United States humanitarian intervention due to the disaster in Somalia in October 1993. This policy then continued as the genocide unfolded, documents showing the U.S. maintaining a strong stance and through political maneuvering was able to get the UNSC to vote for the withdrawal of UNAMIR troops.

The documents show that the United States' hard stance on foreign policy issues are often influenced by actors outside of the Department of State, and often for complex reasons, supporting existing scholarship on the creation of U.S. foreign policy. ${ }^{126}$ The documents provide supporting evidence to the theory that often the NSC makes the final call on U.S. foreign policy in crisis

\footnotetext{
${ }^{118}$ National Security Archive, International Decision-Making, Day 2, Annotated Transcript, 15.

${ }^{119}$ Ibid., 18.

${ }^{120}$ Ibid.,16.

${ }^{121}$ Ibid., 30.

122 Barnett, Eyewitness to Genocide, $\mathrm{x}$.

${ }^{123}$ National Security Council Memorandum to William Itoh, "Discussion Paper for the Deputies Committee on Peacekeeping in Rwanda," Washington, DC: National Security Archive, May 16, 1994, accessed October 12, 2018, https://nsarchive2.gwu.edu/NSAEBB/NSAEBB511/docs/2014-0278-M 19940516.pdf.

${ }^{124}$ National Security Council Memorandum from Donald Steinberg, "Points for POTUS with Members," Washington, DC: National Security Archive, June 14, 1994, accessed October 12, 2018, https://nsarchive2.gwu.edu/NSAEBB/ NSAEBB511/docs/DOCUMENT\%2020.pdf.

${ }^{126}$ Jacobs and Page, Who Influences U.S. Foreign Policy?; Oueslati, U.S. Foreign Policy; Hook, Domestic Obstacles to International Affairs.
} 
situations. This is important for lobbyists, civil society members, and concerned citizens who may want to influence U.S. decision-making and response regarding mass atrocity. It is an important consideration for those working toward supporting better policies to prevent mass human rights violations and genocide in the future.

While this paper analyzed the role of the United States in the U.N.'s decision to withdraw UNAMIR troops, this was only one of the many pieces of the international community's response to the genocide in Rwanda. For example, France played a large role in international decisionmaking in response to the genocide in Rwanda, however access to declassified government information from the French government is extremely limited to non-existent. During the June 2014 conference, former Secretary General of the French Presidency Hubert Védrine said called for the release of French government records relating to the genocide in Rwanda: "France has already made a lot public through the Quilès inquiry, but there are obviously many other documents [still to be released]. I would like to improve access to the archives of all the protagonists." ${ }^{127}$ Additional declassification of French documents could greatly contribute to existing scholarly work on the role of the French in the genocide. It would be beneficial for other scholars to push for declassification of information from other governments and do similar studies to better understand international and foreign policy decision-making, especially for nations who were present in the U.N. Security Council during the genocide in Rwanda.

It would also be beneficial for scholars to heed Nigerian Ambassador Ibrahim Gambari and more closely look at the roles, influence, and position of the non-permanent members and the NAM caucus. He said that a failure to consider the perspectives of states other than the permanent five will cause a continuation of the same issues that led to the failure of the international community's response to Rwanda in 1994. ${ }^{128}$ He stated at the June 2014 conference: "[W]hy is Africa's role always downplayed? It is as if we were ghosts...It is a mindset that continues, I am sorry to say, in the Security Council even today...If we reduce discussion in the Security Council to the preferences of the P5 or the P3, a lot of the issues that we are discussing here will continue. I feel very strongly and passionately about this because I have seen it elsewhere, beyond Rwanda." 129 Further research and genocide prevention work should more fully consider the role of states beyond the permanent members to the UN Security Council.

While the use of critical oral history as a method of participatory action research is an important research tool to more deeply engage the archival record of past conflict and policy in response to genocide, further advancements can be made. Future research using the critical oral history conference methodology could include a wider variety of actors, including members of civil society, allowing for a perspective that is often excluded from national and international levels of policy making. It was an important step in this critical oral history conference to invite the participation of Monique Mujawamariya, a survivor of the genocide and a civil society leader, however, additional voices at the table, and a wider discussion of civil society forces on the ground in Rwanda would have been beneficial to understanding alternative responses to the genocide and possible opportunities for prevention. These viewpoints could lend a further critical eye and deep discussion of the documents themselves, and the context in which the documents were created, leading to a richer understanding of the archives and their historical context of how policy was made and potential alternatives. This could then lead to more successful prevention efforts.

It is also important to note that while the United States government released this large and important new collection of documents in April 2015 about U.S. foreign policy in response to the genocide in Rwanda, important information remains classified. Many of the newly released documents can help us better understand the complicated intricacies of U.S. domestic and foreign policy at the time, but key pieces of information are still not accessible. The U.S. and other foreign governments need to place a high priority on the release of key information related to mass atrocity, genocide and human rights violations that will allow a better understanding of how

\footnotetext{
${ }^{127}$ National Security Archive, International Decision-Making, Day 1, Annotated Transcript, 128.

${ }^{128}$ National Security Archive, International Decision-Making, Day 2, Annotated Transcript, 19; Ibrahim Gambari, interview, June 3, 2014.

${ }^{129}$ National Security Archive, International Decision-Making, Day 2, Annotated Transcript, 18-19.
} 
government policy is made. A better understanding of how policy is created can lead to creating better preventative policy in the future.

\section{Acknowledgements}

The author thanks Tom Blanton of the National Security Archive for his leadership on the "International Decision-Making in the Age of Genocide: Rwanda 1990-1994" project. The author thanks Angelina Godoy at the University of Washington for her support and feedback in the writing of this paper.

\section{Bibliography}

Adelman, Howard and Astri Suhrke. "Early Warning and Response: Why the International Community Failed to Prevent the Genocide." Disasters 20 (1996), 295-304. https://doi. org/10.1111/j.1467-7717.1996.tb01045.x

Albright, Madeleine K. Interview by PBS Frontline. Frontline. February 25, 2004. Accessed October 21, 2018. https://www.pbs.org/wgbh/pages/frontline/shows/ghosts/interviews/albright. html.

-------. Madam Secretary. New York: Miramax Books, 2003.

Barnett, Michael. Eyewitness to a Genocide - The United Nations and Rwanda. Ithaca and London: Cornell University Press, 2002.

Beardsley, Brent. "U.N. Peacekeepers in Rwanda were Ill- Equipped." Interview by Michael Dobbs. Genocide Prevention Project. April 30, 2013. Washington, DC: National Security Archive.

Blanton, Tom and Emily Willard. "1994 Rwanda Pullout Driven by Clinton White House, U.N. Equivocation." Electronic Briefing Book no. 511. Washington, DC: National Security Archive, April 16, 2015. Accessed March 28, 2017. http://nsarchive.gwu.edu/NSAEBB/NSAEBB511/.

Blight, James, and Janet Lang. Dark beyond Darkness: The Cuban Missile Crisis as History, Warning, and Catalyst. Lanham: Rowman \& Littlefield, 2018.

Blight, James, Janet Lang, Hussein Banai, Malcolm Byrne, and John Tirman. Becoming Enemies: U.S.Iran Relations and the Iran-Iraq War, 1979-1988. First paperback edition. Lanham: Rowman \& Littlefield Publishers, 2012.

Boutros- Ghali, Boutros. Interview by PBS Frontline. Frontline. January 24, 2004. Accessed October 10, 2018. https://www.pbs.org/wgbh/pages/frontline/shows/ghosts/interviews/ghali.html.

Bushnell, Prudence. Interview by Michael Dobbs. Genocide Prevention Project. November 22, 2013. Washington DC: United States Holocaust Memorial Museum.

Cable BRUSSE 04128 from U.S. Embassy Brussels to U.S. Secretary of State. "WGRWO1: More on Belgian Position on UNAMIR." Washington, DC: State Department Electronic Reading room, April 12, 1994.

Cable NZUN 2430 from New Zealand Mission to the United Nations to Wellington, N.Z. "Security Council: Rwanda." Washington, DC: National Security Archive, April 13, 1994. Accessed October 21，2018. https://assets.documentcloud.org/documents/1392939/footnote-141nzun-2430.pdf.

Cable State 297511 from U.S. Secretary of State to U.S. Mission to the U.N. "Evening Notes 9/28." Electronic Briefing Book no. 511. Washington, DC: National Security Archive, September 29, 1993. Accessed June 4, 2018. https://nsarchive2.gwu.edu/NSAEBB/NSAEBB511/docs/ DOCUMENT\%202.pdf.

Cable USUN 1588 from U.S. Mission to the U.N to U.S. Secretary of State. "TFRWOL: US Drops Bombshell on Security Council - 4/15." Electronic Briefing Book no. 511. Washington, DC: National Security Archive, April 15, 1994. Accessed June 4, 2018. https://nsarchive2.gwu. edu/NSAEBB/NSAEBB511/docs/DOCUMENT 16.pdf.

Cable USUN 1503 from Madeleine Albright U.S. Mission to U.N. to Secretary of State. "TFRWOL: Future of UNAMIR and French Roles in Rwanda." Electronic Briefing Book no. 511. Washington, DC: National Security Archive, April 12, 1994. Accessed June 4, 2018. https://nsarchive2.gwu.edu/NSAEBB/NSAEBB511/docs/DOCUMENT\%2014.pdf.

Cable USUN 4735 from Madeleine Albright U.S. Mission to the U.N. to U.S. Secretary of State. "Rwanda and Criteria for New UN PKO." Electronic Briefing Book no. 511. Washington, DC: 
National Security Archive, September 28, 1993. Accessed June 4, 2018. https://nsarchive2. gwu.edu/NSAEBB/NSAEBB511/docs/DOCUMENT\%201.pdf.

Code Cable (fax) from Gen. Romeo Dallaire to Maurice Baril, UN DPKO. "Most Immediate." Washington, DC: National Security Archive, January 11, 1994. Accessed December 9, 2018. https://nsarchive2.gwu.edu/NSAEBB/NSAEBB452/docs/doc03.pdf.

Dallaire, Roméo. Shake Hands with the Devil: The Failure of Humanity in Rwanda. Toronto: Random House Canada, 2003.

Des Forges, Alison. "Leave None to Tell the Story": Genocide in Rwanda. New York: Human Rights Watch, 1999.

Dobbs, Michael. "Inside the UN Security Council: April-July 1994." Electronic Briefing Book no. 472. Washington, DC: National Security Archive, June 2, 2014. Accessed December 9, 2018. https://nsarchive2.gwu.edu/NSAEBB/NSAEBB472/.

Gasbarri, Flavia. "Revisiting the Linkage: PDD 25, Genocide in Rwanda and the US Peacekeeping Experience of the 1990s." The International History Review, 40, no. 4 (2017), 792-813. https://doi.org/10.1080/07075332.2017.1354311

Grünfeld, Fred and Anke Huijboom. The Failure to Prevent Genocide in Rwanda: The Role of Bystanders. Leiden and Boston: Martinus Nijhoff Publishers, 2007. https://doi.org/10.1163/ ej.9789004157811.i-299

Hook, Steven. "Domestic Obstacles to International Affairs: The State Department under Fire at Home." PS: Political Science and Politics 36, no. 1 (January 2003), 23-29. https://doi. org/10.1017/S1049096503001641

Jacobs, Lawrence and Benjamin Page. "Who Influences U.S. Foreign Policy?" American Political Science Review 99, no. 1 (February 2005), 107-123. https://doi.org/10.1017/S000305540505152X

Kovanda, Karel. "The Czech Republic on the UN Security Council: The Rwandan Genocide." Genocide Studies and Prevention: An International Journal 5, no. 2 (2010), 192-218. https://doi. org/10.1353/gsp.2010.0006

Kroslak, Daniela. The French Betrayal of Rwanda. Bloomington and Indianapolis: Indiana University Press, 2008.

Lake, Tony. Interview by PBS Frontline. Frontline. December 15, 2003. Accessed October 17, 2018. https://www.pbs.org/wgbh/pages/frontline/shows/ghosts/interviews/lake.html.

Levinger, Matthew. "Why the U.S. Government Failed to Anticipate the Rwandan Genocide of 1994: Lessons for Early Warning and Prevention." Genocide Studies and Prevention 9, no. 3 (2016), 33-58. https://doi.org/10.5038/1911-9933.9.3.1362

Melvern, Linda. A People Betrayed: The Role of the West in Rwanda's Genocide. Cape Town, London, and New York: Zed Books, 2000.

-------. Conspiracy to Murder: The Rwandan Genocide. Revised edition. London and New York: Verso, 2006.

Memorandum from MacArthur DeShazer to Tony Lake et al. "Rwanda Update." Electronic Briefing Book no. 511. Washington, DC: National Security Archive, April 14, 1994. Accessed June 4, 2018. https://nsarchive2.gwu.edu/NSAEBB/NSAEBB511/docs/DOCUMENT\%2015.pdf.

Memorandum from Richard Clarke to Donald Steinberg. "Rwanda: Next Steps for Sunday and Beyond." Electronic Briefing Book no. 511. Washington, DC: National Security Archive, April 9, 1994. Accessed June 4, 2018. https://nsarchive2.gwu.edu/NSAEBB/NSAEBB511/docs/ DOCUMENT\%209.pdf.

Memorandum from Richard Clarke and Susan Rice to Tony Lake. "Draft Message to General Quesnot on Rwanda Peacekeeping." Washington, DC: National Security Archive, October 1, 1993. Accessed June 4, 2018. https://nsarchive2.gwu.edu/NSAEBB/NSAEBB511/docs/ DOCUMENT\%204.pdf.

Moose, George. Interview by PBS Frontline. Frontline. November 21, 2003. Accessed October 10, 2018. https://www.pbs.org/wgbh/pages/frontline/shows/ghosts/interviews/moose.html.

National Security Archive. "International Decision-Making in the Age of Genocide: Rwanda 19901994, Annotated Transcript, Day 1." National Security Archive and United States Holocaust Memorial Museum, June 2, 2014. Accessed December 9, 2018. https://nsarchive2.gwu.edu/ NSAEBB/NSAEBB508/docs/Rwanda\%20Final\%20Transcript\%20Day\%201.pdf. 
. "International Decision-Making in the Age of Genocide: Rwanda 1990-1994, Annotated Transcript, Day 2." National Security Archive and United States Holocaust Memorial Museum, June 3, 2014. Accessed December 9, 2018. https://nsarchive2.gwu.edu/NSAEBB/ NSAEBB508/docs/Rwanda Final Transcript Day 2.pdf.

National Security Council Memorandum from Donald Steinberg. "Points for POTUS with Members." Washington, DC: National Security Archive, June 14, 1994. Accessed October 12, 2018. https://nsarchive2.gwu.edu/NSAEBB/NSAEBB511/docs/DOCUMENT\%2020.pdf.

National Security Council Memorandum from Eric Schwartz to Susan Rice and Donald Steinberg. "Pull-out of UNAMIR." Washington, DC: National Security Archive, April 19, 1994. Accessed December 9, 2018. https://nsarchive2.gwu.edu/NSAEBB/NSAEBB511/docs/20140278-M 19940419.pdf.

National Security Council Memorandum from Susan Rice to Tony Lake. "Five Imminent New UN Peacekeeping Operations." Electronic Briefing Book no. 511. Washington, DC: National Security Archive, August 2, 1993. Accessed October 10, 2018. https://nsarchive2.gwu.edu/ NSAEBB/NSAEBB511/docs/2014-0278-M 19930802.pdf.

National Security Council Memorandum to William Itoh. "Discussion Paper for the Deputies Committee on Peacekeeping in Rwanda." Washington, DC: National Security Archive, May 16, 1994. Accessed October 12, 2018. https://nsarchive2.gwu.edu/NSAEBB/NSAEBB511/ docs/2014-0278-M 19940516.pdf.

Oueslati, Salah. "U.S. Foreign Policy and the Complex Factors of Decision-Making." Society 51, no. 5 (2014), 472-481. https://doi.org/10.1007/s12115-014-9813-y

Power, Samantha. A Problem from Hell: America and the Age of Genocide. New York: Basic Books, 2002.

Prunier, Gérard. The Rwanda Crisis: History of a Genocide. New York: Columbia University Press, 1995.

Secret Memorandum. "Assessment: Peacekeeping Operations in Rwanda." Electronic Briefing Book no. 511. Washington, DC: National Security Archive, September 30, 1993. Accessed June 4, 2018. https://nsarchive2.gwu.edu/NSAEBB/NSAEBB511/docs/DOCUMENT\%203.pdf.

Shattuck, John. Freedom on Fire: Human Rights Wars and America's Response. London and Cambridge: Harvard University Press, 2003.

Stoler, Ann Laura. "Colonial Archives and the Arts of Governance: On the Content in the Form." In Archives, Documentation, and Institutions of Social Memory: Essays from the Sawyer Seminar, edited by Francis X. Blouin and William G. Rosenberg, 267-279. Ann Arbor: University of Michigan Press, 2006.

Willard, Emily. "The Rwanda Sitreps: Daily Pleas to New York Detail How International Failure Left Peacekeepers Ill-Equipped to Respond to Rising Violence in January 1994." Electronic Briefing Book no. 455. Washington, DC: National Security Archive, February 3, 2014. Accessed March 28, 2017. http://www2.gwu.edu/ nsarchiv/NSAEBB/NSAEBB455/.

. "Key Diplomat's Personal Notebook Sheds Light on Inner Workings of US Government Response to Genocide Unfolding in Rwanda in 1994." Electronic Briefing Book no. 500. Washington, DC: National Security Archive, January 30, 2015. Accessed December 9, 2018. http://nsarchive2.gwu.edu/NSAEBB/NSAEBB500/.

Willard, Emily, and Jake Freyer. "Sitreps Detail Rwanda's Descent into Genocide 1994." Electronic Briefing Book no. 466. Washington, DC: National Security Archive, April 7, 2014. Accessed March 28, 2017. http://nsarchive.gwu.edu/NSAEBB/NSAEBB466/. 